\title{
POTRET PENDIDIKAN DAN KEMISKINAN DI INDONESIA DALAM NOVEL LASKAR PELANGI KARYA ANDRE HIRATA
}

Portrait of Education and Poverty in Indonesia

in the novel Laskar Pelangi by Andre Hirata

\author{
Rini Widiastuti \\ Balai Bahasa Provinsi Jawa Barat \\ Riniwidi2275@gmail.com
}

\section{Naskah Diterima Tanggal 17 November 2021-Direvisi Akhir Tanggal 20 Desember 2021-Disetujui Tanggal 28 Desember 2021} doi: https://doi.org/10.26499/jentera.v10i2.4372

\begin{abstract}
Abstrak
Tulisan ini akan meneliti dan merenungkan hubungan antara sastra dan pendidikan, dengan menjurus kepada persoalan di sekitar perkembangan sistem pendidikan di Indonesia melalui "kacamata" Laskar Pelangi karya Andrea Hirata. Andrea Hirata menunjukkan lewat novel Laskar Pelangi bahwa pendidikan bukanlah tempat seseorang menuntut ilmu, tetapi bagaimana menjalaninya. Secara signifikan, masalah yang paling menonjol yang dibicarakan dalam novel Laskar Pelangi adalah tema pendidikan di Indonesia dan penulis tertarik untuk melihat masalah tersebut melalui persoalan kenyataan pasang-surut pendidikan di Indonesia. Adapun untuk tujuan tersebut, penulis melakukan analisis atas masalah yang hendak disoroti dengan menggunakan metode genetikstrukturalisme. Penggunaan metode ini didasarkan pada alasan bahwa pendidikan seperti apa yang terkandung dalam novel Laskar Pelangi adalah refleksi dari suatu realitas pendidikan di Indonesia. Demi memahami persoalan tersebut lebih jelas, maka analisis terhadap novel tersebut tidak hanya dilakukan untuk melihat persoalan pendidikan tersebut seperti apa yang terdapat dalam novel (intrinsik), tetapi juga dalam hal referensinya ke dunia nyata pendidikan Indonesia (ekstirinsik).
\end{abstract}

Kata kunci: Laskar Pelangi, sastra, intrinsik, ekstrinsik, dan pendidikan.

\begin{abstract}
This paper will examine and reflect on the relationship between literature and education, by addressing the issues surrounding the development of the education system in Indonesia through Andrea Hirata's Laskar Pelangi "glasses". Andrea Hirata shows through the novel Laskar Pelangi that education is not a place where one seeks knowledge, but how to live it. Significantly, the most prominent problem discussed in the novel Laskar Pelangi is the theme of education in Indonesia, and the author is interested in seeing this problem through the realities of the ups and downs of education in Indonesia. As for this purpose, the author analyzes the problems to be highlighted by using the genetic-structuralism method. The use of this method is based on the reason that education like what is contained in the novel Laskar Pelangi is a reflection of the reality of education in Indonesia. And in order to understand the issue more clearly, the analysis of the novel will not only look at the educational issues as contained in the novel (intrinsic), but also in terms of their references to the real world of Indonesian education (extrinsic). Keyword: Laskar Pelangi, literature, intrinsic, extrinsic, and education
\end{abstract}

How to Cite: Widyastusi, Rini. (2021). Potret Pendidikan dan Kemiskinan di Indonesia dalam Novel Laskar Pelangi Karya Andre Hirata. Jentera: Jurnal Kajian Sastra, 10(2), 209-221. doi: https://doi.org/10.26499/jentera.v10i2.4372

\section{PENDAHULUAN}

Pendidikan menjadi tolok ukur kemajuan suatu bangsa karena salah satu unsur penting kemajuan tersebut adalah sumber daya manusia. Kualitas SDM dapat dilihat dari seberapa tinggi mutu pendidikannya; bagaimana kualitas pendidiknya, sarana dan prasarana, dan penunjang lainnya. Akhir-akhir ini pemberitaan mengenai bobroknya akhlak seorang pendidik 
yang dengan dalih apapun yang menodai anak didiknya sendiri muncul. Para siswa yang harus menempuh berkilo-kilo, menyebrang sungai demi menuntut ilmu, dan masih adanya diskriminasi antara siswa yang mampu dengan yang kurang mampu. Kenyataan itulah yang menjadi warna pendidikan Indonesia.

Karya sastra (khususnya novel) yang berani atau nekat mengangkat tema pendidikan, masih sedikit bisa ditemukan di Indonesia. Tema seperti ini agaknya cukup dihindari oleh ratarata penulis dan juga penerbit karena agaknya dianggap tidak laku, kurang menjual, atau rumit. Lihat saja carut-marut dunia pendidikan Indonesia, apa lagi hal menarik yang bisa diangkat dari segala sisi yang memang sudah sungguh "tak menarik"? Membicarakan pendidikan di Indonesia adalah menyibak luka tentang sebuah sistem yang komplikatif, sekolah-sekolah yang kurang fasilitasi, guru-guru bergaji rendah dan para siswa yang hobi tawuran. Singkat kata, pendidikan adalah semacam penyakit kronis yang tampak semakin sulit disembuhkan dan bukan hal yang cukup menarik untuk dibicarakan apalagi sekadar diperhatikan.

Namun tidak bagi Andrea Hirata. Ketika ia kemudian datang dan menawarkan sebuah karya (novel) yang ia tulis--dengan tema pendidikan, dalam cakupan perspektif yang sama sekali berbeda dari bagaimana kita menganggap pendidikan selama ini: gairah baru pun kembali bangkit. Andrea sanggup membuktikan bahwa, pendidikan dan perbincangan tentangnya-sebagaimana yang kita kenal selama ini--tidaklah "seseram" seperti yang ada dalam bayangan kita tiap kali mendengarnya disebutkan. Pendidikan justru merupakan sesuatu yang sangat menarik, yang harus diselami dengan penuh semangat dan komitmen, seperti ditunjukkan oleh sebelas orang anggota Laskar Pelangi dalam novel semi-autobiografi Andrea Hirata.

Tak dapat dipungkiri, novel tersebut berangkat dari pengalaman masa lalu Andrea sendiri, bersama 10 orang anak "nakal" yang merupakan teman masa kecilnya di SD Muhammadiyah Belitong yang miskin, Andrea hendak berbagi kepada masyarakat Indonesia dan menunjukkan pada kita bahwa dengan semangat untuk mengenyam pendidikan dan menuntut ilmu masih ada dan akan tetap ada. Malah hal tersebut justru datang dari tempat yang paling tidak pernah disangka-sangka: sebuah sekolah miskin--dan bagi anak-anak dari latar belakang ekonomi keluarga yang pula miskin--yang nyaris ambruk dengan parah!

Ironis memang. Namun demikianlah kenyataan, sebagaimana Andrea Hirata bersama komplotan Laskar Pelangi bermaksud menyadarkan kita dari semacam tidur panjang mimpi utopis tentang pendidikan di negeri ini. Laskar Pelangi sanggup membawa paradigma baru dan menjungkirkan perspektif kita selama ini tentang bagaimana memandang pendidikan di tanah sendiri dan menantang untuk melakukan sesuatu demi memperbaikinya dan memajukannya. Berangkat dari sebuah kisah nyata masa kecil Andrea Hirata, Laskar Pelangi berubah wujud menjadi sebuah pelajaran berharga atas nama pendidikan itu sendiri. Semoga pujian apapun yang ditujukan terhadap novel best-seller ini, tidak hanya akan berhenti sampai di situ saja, melainkan mampu menghadirkan semacam inspirasi untuk melakukan perubahan yang terbaik demi pendidikan di negeri ini.

Pada dasarnya, Laskar Pelangi sendiri merupakan bagian dari novel tetralogi (empat serangkai: Laskar Pelangi, Sang Pemimpi, Edensor dan Maryamah Karpov) karya Andrea Hirata, yang memang difokuskan pada isu tentang pendidikan. Namun untuk melakukannya dengan lebih terarah, pembahasan hanya akan dilakukan dengan mengambil bagian pertama dari tetralogi Laskar Pelangi karya Andrea Hirata, yakni novel Laskar Pelangi itu sendiri, dalam hal hubungannya dengan pendidikan di Indonesia. Adapun demi keperluan tersebut, maka sebuah langkah pengkajian pun perlu dilakukan dengan menggunakan metode pendekatan genetik-strukturalisme.

Pencarian untuk menemukan seberapa banyak hal yang berkaitan dengan pendidikan dan pasang-surut pendidikan di Indonesia dalam novel Laskar Pelangi perlu dilakukan dengan berpijak pada kerangka genetik-strukturalisme. Penggunaan metode ini didasarkan pada alasan 
bahwa pendidikan seperti apa yang terkandung dalam novel Laskar Pelangi adalah refleksi dari suatu realitas pendidikan di Indonesia. Pendekatan ini pun dilakukan dengan maksud untuk melihat bagaimana tema pendidikan tersebut dituangkan dalam novel (intrinsik) dan referensinya dengan dunia nyata pendidikan di Indonesia (ekstrinsik), mengingat kenyataan bahwa Laskar Pelangi merupakan sebuah novel semi-autobiografi yang mendasarkan penciptaannya pada keterlibatan pengalaman penulisnya sendiri.

Penelitian-penelitian yang serupa telah dilakukan seperti Nani Anggraini (2019) menganalisis tentang strukturalisme genetik dalam novel Midah Simanis Bergigi Emas karya Pramoedya Ananta Toer. Bagaimana pandangan dunia menurut pengarang dalam novel tersebut. Pandangan dunia memicu subjek untuk mengidentifikasi pandangan dunia.

Fitria (2017) menulis tentang strukturalisme genetik dengan judul Strukturalisme Genetik dalam Novel Fadaituki Ya Laila Karya Yusuf Siba'i (Pendekatan Deskriptif Analisis). Berdasarkan hasil penelitian ditemukan pengertian strukturalisme genetik dan unsur-unsur intrinsik yaitu tema, penokohan, alur, dan unsur-unsur ekstrinsik yaitu fakta kemanusiaan, subjek kolektif, struktur karya sastra, pemahaman-penjelasan, dan pandangan dunia.

Tulisan Toto Mustomi dan Sirojul Munir (2018) dilatarbelakangi oleh kurang berperan aktifnya pembelajaran sastra di Indonesia yang diberi judul Kajian Strukturalisme Genetik dalam Novel Eliana Karya Tere Liye. Mereka membahas struktural genetik dalam novel Eliana dan kesesuaiannya sebagai bahan ajar menulis resensi novel di SMA serta model bahan ajarnya.

\title{
LANDASAN TEORI
}

\section{Pendekatan Genetik-Strukturalisme}

Pendekatan genetik-strukturalisme merupakan pengembangan dari pendekatan strukturalisme konvensional. Secara umum, jenis pendekatan yang paling sering digunakan oleh para peneliti sastra adalah pendekatan intrinsik dan ekstrinsik. Namun dalam menerapkan teori pendekatan genetik-strukturalisme, hal yang pertama-tama harus diperhatikan adalah elemen-elemen struktural dalam karya sastra tersebut (intrinsik), kemudian keadaan sosial yang dibawa oleh karya itu (ekstrinsik), seperti apa yang dinyatakan oleh Goldmann, dikutip oleh Iswanto.

\begin{abstract}
"Pandangan dunia yang ditampilkan pengarang lewat problematic hero merupakan suatu struktural global yang bermakna. Pandangan dunia ini bukan semata-mata pandangan empiris yang bersifat langsung, tetapi merupakan suatu gagasan, aspirasi dan perasaan yang dapat mempersatukan kelompok sosial masyarakat. Pandangan dunia itu memperoleh bentuk konkrit di dalam karya sastra. Pandangan dunia bukan fakta. Pandangan dunia tidak memiliki eksistensi obyektif, tetapi merupakan ekspresi dari kondisi dan kepentingan suatu golongan masyarakat tertentu." (Jabrohim, Ed., 1994: 79).
\end{abstract}

Pendekatan genetik-strukturalisme merupakan pendekatan yang digunakan untuk menganalisis karya sastra yang timbul sebagai reaksi dari pendekatan strukturalisme murni. Kekurangan dari pendekatan strukturalisme klasik, dilengkapi dengan elemen genetik (ekstrinsik) suatu karya sastra, baik itu mengacu pada keadaan masyarakat yang mendasarkan penciptaan karya sastra tersebut maupun keterlibatan penulis sendiri dalam apa yang dituliskannya. Pendekatan strukturalisme atau lebih dikenal juga sebagai pendekatan obyektif lebih memusatkan analisis terhadap elemen-elemen intrinsik, seperti plot, karakter, setting, tema, konflik dan sebagainya. Sementara pendekatan genetik-strukturalisme menunjukkan bahwa dalam penciptaan suatu karya sastra, tidak pernah terlepas dari latar belakang sejarah, masa, situasi sosial maupun pandangan dan pengalaman hidup dari penulisnya sendiri. Ini berarti bahwa keberadaan suatu kelompok masyarakat tertentu dan penulis tertentu juga akan menghasilkan suatu karya tertentu. Hal ini turut disepakati oleh Iswanto bahwa: 
"Karya sastra lahir di tengah-tengah masyarakat sebagai hasil imajinasi pengarang serta refleksinya terhadap gejala-gejala sosial disekitarnya. Oleh karena itu, kehadiran karya sastra merupakan bagian dari kehidupan masyarakat. Pengarang sebagai subyek individual mencoba menghasilkan pandangan dunianya kepada subyek kolektifnya. signifikansi yang dielaborasikan subyek individual terhadap realitas sosial yang disekitarnya menunjukkan sebuah karya berakar pada kultur dan masyarakat tertentu." (Jabrohim, ed., 1994: 78)

Oleh karena itu, karya sastra yang dianalisa dengan menggunakan pendekatan genetikstrukturalisme harus memperhatikan elemen intrinsik dari penciptaan itu sendiri dan menyadari secara intrinsik, bahwa karya itu diciptakan dengan merujuk pada kenyataan yang sungguh terjadi di tengah masyarakat.

\section{Elemen-elemen Intrinsik}

Adapun elemen-elemen intrinsik yang perlu dikaji pada sebuah karya sastra adalah bagian di mana elemen-elemen seperti tokoh dan penokohan (characters and characterization), alur (plot), tema (theme), dan latar (setting) saling terkait satu sama lain. Namun, dalam tulisan ini pembahasan hanya akan dilakukan dengan mengkaji elemen intrinsik tema pokok dalam novel secara khusus, yakni perihal pendidikan. Tentu saja, meskipun telah selesai dengan mengkaji elemen-elemen intrinsik dalam sebuah karya sastra, namun dalam pendekatan Genetik-Strukturalisme, analisis tersebut belum dapat dapat dikatakan memenuhi, sebab elemen-elemen ekstrinsik yang menjadi dasar penciptaan sebuah karya sastra juga tidak dapat diabaikan.

\section{Elemen-elemen Ekstrinsik}

Begitu banyak hal yang bisa menjadi dasar ekstrinsik penciptaan sebuah karya sastra, baik itu mengacu pada pengalaman mendasar penulisnya sendiri, suatu kenyataan atas keadaan yang berlaku secara umum di masyarakat, maupun berangkat dari semacam kritik sosial atas suatu keadaan masyarakat tertentu.

Adapun dalam novel karya Andrea Hirata tersebut, hampir semua bagian elemen ektrinsik berlaku. Laskar Pelangi merupakan sejarah keterlibatan penulisnya terhadap karya yang ia buat dan dapat pula dikatakan sebagai suatu kenyataan dan kritik sosial atas suatu keadaan tertentu yang berlaku secara umum di masyarakat: keadaan carut-marut dan pasangsurut dunia pendidikan di Indonesia. Adapun, dalam tulisan ini, sebuah pengkajian atas kenyataan tersebut dapat dilakukan dengan menggabungkan berbagai unsur intrinsik dan ekstrinsik dari karya yang dibahas, untuk dapat menampilkannya sebagai suatu potret pendidikan bangsa yang utuh.

\section{PEMBAHASAN}

\section{Struktur Intrinsik: Sebuah Arus Pasang}

Laskar Pelangi dibuka di sebuah sekolah miskin SD Muhammadiyah Belitong (Belitung) pada hari pertama penerimaan siswa baru. Tokoh utama "Aku" yang merupakan representatif-perspektif Andrea Hirata kecil sendiri tengah berada di sana bersama anak-anak lain (calon anggota apa yang mereka sebut dengan "Laskar Pelangi") dan ayah mereka, di halaman luas sekolah yang "goyah" itu, mengelilingi sebatang pohon filicium tua.

PAGI itu, waktu aku masih kecil, aku duduk di bangku panjang di depan sebuah kelas. Sebatang pohon filicium tua yang rindang meneduhiku. Ayahku duduk di sampingku, memeluk pundakku dengan kedua lengannya dan tersenyum mengangguk-angguk pada setiap orang tua dan anak-anaknya yang duduk berderet-deret dibangku panjang lain di depan kami. Hari itu adalah hari yang agak penting: hari pertama masuk SD. (Hirata, 2006:1) 
Namun sesungguhnya hari pertama penerimaan siswa baru tersebut merupakan awal dari serangkaian drama atas pendidikan yang telah sekian lama menimpa sekolah tersebut. Kesan yang digambarkan adalah bahwa pada hari pertama penerimaan siswa baru yang umumnya merupakan masa yang penuh sukacita, kesibukan dan hiruk-pikuk di sekolah yang lain, bukanlah apa yang terjadi di sekolah miskin itu. Dua orang guru yang bergulat demi menghidupkan geliat sekolah tersebut, Pak Harfan dan Bu Mus adalah sosok yang paling tampak cemas ketika itu.

$\mathrm{Bu}$ Mus yang semakin khawatir memancang pandangannya ke jalan raya di seberang lapangan sekolah berharap kalau-kalau masih ada pendaftar baru. Kami prihatin melihat harapan hampa itu. Maka tidak seperti suasana SD lain yang penuh kegembiraan ketika menerima murid angkatan baru, suasana hari pertama SD Muhammadiyah penuh dengan kerisauan, dan yang paling risau adalah Bu Mus dan Pak Harfan. (Hirata,2006:4)

Pasalnya adalah peringatan yang diterima oleh pengawas sekolah dari Depdikbud Sumsel, yang memberlakukan ancaman untuk menutup sekolah tersebut jika murid baru yang diterima kurang dari sepuluh, kenyataan seperti itu adalah sesuatu yang sangat tidak diharapkan oleh Pak Harfan dan Bu Mus. Sementara calon siswa baru yang berminat masuk sekolah tersebut dan sedang menunggu kesempatan untuk itu baru sebanyak sembilan orang.

Guru-guru yang sederhana ini berada dalam situasi genting karena Pengawas Sekolah dari Depdikbud Sumsel telah memperingatkan bahwa jika SD Muhammadiyah hanya mendapat murid baru kurang dari sepuluh orang maka sekolah paling tua di Belitong ini harus ditutup. Karena itu sekarang Bu Mus dan Pak Harfan cemas sebab sekolah mereka akan tamat riwayatnya, sedangkan para orang tua cemas karena biaya, dan kami, sembilan anak-anak kecil ini--yang terperangkap di tengah--cemas kalau-kalau kami tak jadi bersekolah. (Hirata, 2006:4-5)

Sementara bagi para orang tua yang hendak mendaftarkan anak mereka di sekolah itu pun tengah menghadapi dilema yang lain. Mereka berasal dari rata-rata keluarga yang paling miskin di Belitong. Selain itu, pendidikan--dalam hal ini menyekolahkan anak-anak mereka-merupakan sebuah barang yang sama sekali "mewah". Bahkan sekolah merupakan sesuatu yang sungguh asing bagi mereka. Mereka, secara turun-temurun, tak pernah satu pun mengenyam pendidikan. Bekerja adalah jauh lebih baik daripada bersekolah, sebab bermanfaat untuk mencari nafkah. Namun tentu saja hal tersebut merupakan sesuatu yang sangat dilematis bagi mereka, sebab sungguh mereka menyadari betapa pentingnya pendidikan untuk lepas dari jeratan kemiskinan.

Para orang tua mungkin menganggap kekurangan satu murid sebagai pertanda bagi anak-
anaknya bahwa mereka memang sebaiknya didaftarkan pada para juragan saja. Sedangkan
aku agaknya dan agaknya juga anak-anak yang lain merasa amat pedih: pedih pada orang
tua kami yang tak mampu, pedih menyaksikan detik-detik terakhir sebuah sekolah tua yang
tutup justru pada hari pertama kami ingin sekolah, dan pedih pada niat kuat kami untuk
belajar tapi tinggal selangkah lagi harus terhenti hanya karena kekurangan satu murid. Kami
menunduk dalam-dalam. (Hirata, 2006:5)

Sesungguhnya menjadikan SD Muhammadiyah Belitong sebagai pilihan bagi anakanak mereka bersekolah adalah sesuatu yang tak terelakkan sehubungan dengan kemiskinan yang mereka alami. Dapat dikatakan bahwa sesungguhnya para orang tua tersebut tidak memiliki pilihan lain, selain memasukkan anak-anak mereka ke sekolah itu. Tentu saja dengan pertimbangan tertentu. 
Kami bertetangga dan kami adalah orang-orang Melayu Belitong dari sebuah komunitas paling miskin di pulau itu. Adapun sekolah ini, SD Muhammadiyah Belitong, juga sekolah kampung paling miskin di Belitong. Ada tiga alasan mengapa para orang tua mendaftarkan anaknya di sini. Pertama, karena sekolah Muhammadiyah tidak menetapkan iuran dalam bentuk apapun, para orang tua hanya menyumbang sukarela semampu mereka. Kedua, karena firasat, anak-anak mereka dianggap memiliki karakter yang mudah disesatkan iblis sehingga sejak usia muda harus mendapat pendadaran Islam yang tangguh. Ketiga, karena anaknya memang tak diterima di sekolah mana pun. (Hirata, 2006:4)

Namun sesungguhnya tak ada yang pernah mengetahui akan ke mana takdir membawa hidup seseorang. Demikian juga bagi anak-anak kecil--yang begitu bersemangat untuk bersekolah--dari sekelompok keluarga paling miskin di Belitong. Mereka yang sedang menunggu kesempatan untuk mengecap "kemewahan" itu, dan nyaris dikecewakan oleh kenyataan bahwa untuk itu mereka masih kekurangan satu orang "teman" saja, serta Pak Harfan yang telah menyiapkan semacam pidato penutupan dan Bu Mus yang mulai berlinangan airmata membayangkan pembubaran sekolahnya, dan orang tua yang mulai lega karena tidak lagi dihantui persoalan biaya, mereka semua dikejutkan ketika itu. Tepat ketika Pak Harfan telah mulai menyalami para orang tua dengan sedih sebagai semacam perpisahan dan hendak memulai pidato penutupannya, seorang anggota baru sekolah mereka (dan kelak anggota dari para Laskar Pelangi), hadir tanpa diduga-duga.

Pak Harfan menghampiri orang tua murid dan menyalami mereka satu persatu. Sebuah pemandangan yang pilu. Para orang tua menepuk-nepuk bahunya untuk membesarkan hatinya. Mata Bu Mus berkilauan karena air mata yang menggenang. Pak Harfan berdiri di depan para orang tua, wajahnya muram. Beliau bersiap-siap memberikan pidato terakhir. Wajahnya tampak putus asa. Namun ketika beliau akan mengucapkan Assalamu'alaikum seluruh hadirin terperanjat karena Trapani berteriak sambil menunjuk ke pinggir lapangan rumput luas halaman sekolah itu.

"Harun!" (Hirata, 2006:6)

Genap sepuluh orang. Maka jadilah mereka memulai tahun ajaran baru ketika itu. Sepuluh orang murid baru dengan semangat yang menggebu-gebu dan dua orang guru dengan pengabdian untuk memberikan segala yang terbaik.

Harun tersenyum lebar memamerkan gigi-giginya yang kuning panjang-panjang. Pak Harfan juga tersenyum, beliau melirik Bu Mus sambil mengangkat bahunya.

"Genap sepuluh orang...," katanya. Harun telah menyelamatkan kami dan kami pun bersorak. Sahara berdiri tegak merapikan lipatan jilbabnya dan menyandang tasnya dengan gagah, ia tak mau duduk lagi. Bu Mus tersipu. Air mata guru muda ini surut dan ia menyeka keringat di wajahnya yang belepotan karena bercampur dengan bedak tepung beras. (Hirata, 2006:7-8)

Sekolah SD Muhammadiyah adalah sebuah institusi yang sungguh-sungguh sederhana, tetapi betul-betul berada pada tahap yang sangat mengkhawatirkan. Sekolah tersebut kekurangan guru dan fasilitas yang memadai. Dengan jumlah kelas dan siswa yang terbatas dan merupakan salah satu dari ratusan hingga bahkan ribuan sekolah miskin lain di negara ini.

Tak susah melukiskan sekolah kami, karena sekolah kami adalah salah satu dari ratusan atau mungkin ribuan sekolah miskin di seantero negeri ini yang jika disenggol sedikit saja oleh kambing yang senewen ingin kawin, bisa rubuh rubuh berantakan.

Kami memiliki enam kelas kecil-kecil, pagi untuk SD Muhammadiyah dan sore untuk SMP Muhammadiyah. Maka kami, sepuluh siswa baru ini bercokol selama sembilan tahun di sekolah yang sama dan kelas-kelas yang sama dengan kelas-kelas yang sama, bahkan susunan kawan sebangku pun tak pernah berubah selama sembilan tahun SD dan SMP itu. 
Kami kekurangan guru dan sebagian besar siswa SD Muhammadiyah ke sekolah memakai sandal. Kami bahkan tak punya seragam. Kami juga tak punya kotak P3K. (Hirata, 2006:1718)

Namun sesungguhnya sekolah tersebut, dan siapa pun yang bersekolah di sana sangatlah beruntung, sebab mereka memiliki guru-guru--paling tidak dua orang, yakni Pak Harfan dan $\mathrm{Bu}$ Mus--yang paling berdedikasi dan berkomitmen secara total terhadap pendidikan. Di luar kenyataan bahwa hal tersebut tidak memberikan keuntungan secara finansial sedikitpun kepada mereka; sesuatu yang mungkin agak sulit untuk ditemukan bahkan pada sekolah paling mahal dan mewah sekalipun.

\begin{abstract}
Maka pada intinya, tak ada yang baru dalam pembicaraan tentang sekolah yang atapnya bocor, berdinding papan, berlantai tanah, atau yang kalau malam dipakai untuk menyimpan ternak, semua itu telah dialami oleh sekolah kami.lebih menarik membicarakan tentang orang-orang seperti apa yang rela menghabiskan hidupnya bertahan di sekolah macam ini. Orang-orang itu tentu saja kepala sekolah kami Pak K. A. Harfan Efendy Noor bin K. A. Fadillah Zein Noor dan Ibu N. A. Muslimah Hafsari Hamid binti K. A. Abdul Hamid. (Hirata, 2006:20)
\end{abstract}

Pak Harfan dan $\mathrm{Bu}$ Mus sanggup mewakili sosok guru ideal bagi para siswa yang mereka naungi. Mereka tidak hanya sebagai guru dalam arti yang wajar, tetapi juga merupakan mentor, penjaga, sahabat, pengajar, dan guru spiritual bagi para murid-muridnya. Merekalah yang pantas disebut sebagai pahlawan tanpa tanda jasa sesungguhnya. Mereka adalah implikasi dari semboyan Muhammadiyah, amar makruf nahi mungkar (menyuruh pada yang makruf dan mencegah dari yang mungkar) yang sebenarnya.

Bagi kami Pak Harfan dan Bu Mus adalah pahlawan tanpa tanda jasa yang sesungguhnya. Merekalah mentor, sahabat, pengajar, dan guru spiritual. Mereka yang pertama menjelaskan secara gamblang implikasi amar makruf nahi mungkar sebagai pegangan moral kami sepanjang hayat. Mereka mengajari kami membuat rumah-rumahan dari perdu apit-apit, mengusap luka-luka di kaki kami, membimbing kami cara mengambil wudu, melongok ke dalam sarung kami ketika kami disunat, mengajari kami doa sebelum tidur, memompa ban sepeda kami, dan kadang-kadang membuatkan kami air jeruk sambal. (Hirata, 2006:32)

Seperti pohon filicium tua di depan sekolah yang menopang kelangsungan hidup ekosistem di sekitarnya, seperti itulah sosok dan arti Pak Harfan serta Bu Mus bagi muridmuridnya.

Mereka adalah ksatria tanpa pamrih, pangeran keikhlasan, dan sumur jernih ilmu pengetahuan di ladang yang ditinggalkan. Sumbangan mereka laksana manfaat yang diberikan pohon filicium yang menaungi atap kelas kami. Pohon ini meneduhi kami dan dialah saksi seluruh drama ini. Seperti guru-guru kami, filicium memberi napas kehidupan bagi ribuan organisme dan menjadi tonggak penting mata rantai ekosistem. (Hirata, 2006:32-33)

Pak Harfan dan Bu Mus berhak untuk menerima penghargaan dan kesan yang setinggi itu dari para murid-muridnya sebab mereka sanggup menunjukkan pada mereka dan menghadirkan pada mereka betapa pentingnya arti pendidikan bagi mereka, di luar kenyataan betapa mereka kurang beruntung memiliki sekolah yang seolah tak layak dan keseringan mereka mengeluhkannya.

Pada kesempatan lain, karena masih kecil tentu saja, kami sering mengeluh mengapa sekolah kami tak seperti sekolah-sekolah lain. Terutama atap sekolah yang bocor dan sangat menyusahkan saat musim hujan. Beliau tak menanggapi keluhan itu tapi mengeluarkan 
sebuah buku berbahasa Belanda dan memperlihatkan sebuah gambar. Gambar itu adalah sebuah ruangan yang sempit, dikelilingi tembok tebal yang suram, tinggi, gelap, dan berjeruji. Kesan di dalamnya begitu pengap, angker, penuh kekerasan dan kesedihan."Inilah sel Pak Karno di sebuah penjara di Bandung, di sini beliau menjalani hukuman dan setiap hari belajar, setiap waktu membaca buku. Beliau adalah salah satu orang tercerdas yang pernah dimiliki bangsa ini."

Beliau tak melanjutkan ceritanya. (Hirata, 2006:31)

Namun ternyata cerita itu sanggup "menyihir" dan menginspirasi mereka. Karena cerita itu telah menimbulkan semacam kesadaran bahwa belajar tidaklah bergantung pada di mana mereka melakukannya, tetapi bagaimana tekad mereka untuk itu. Bahkan pada sekolah paling miskin di Belitong sekalipun. Maka sejak saat itu mereka tak lagi mengeluhkan keadaan sekolah mereka dan tak pernah membolos bahkan hanya sekalipun.

\begin{abstract}
Kami tersihir dalam senyap. Mulai saat itu kami tak pernah lagi memprotes keadaan sekolah kami. Pernah suatu ketika hujan turun amat lebat, petir sambar menyambar. Trapani dan Mahar memakai terindak, topi kerucut dari daun lais khas tentara Vietkong, untuk melindungi jambul mereka. Kucai, Borek, dan Sahara memakai jas hujan kuning bergambar gerigi metal besar di punggungnya dengan tulisan "UPT Bel" (Unit Penambangan Timah Beliton)--jas hujan jatah PN Timah milik bapaknya. Kami sisanya hampir basah kuyup. Tapi sehari pun kami tak pernah bolos, dan kami tak pernah mengeluh, tidak, sedikit pun kami tak pernah mengeluh. (Hirata, 2006:32)
\end{abstract}

Hingga bagi Andrea kecil--atau si Ikal--("Aku") ia merasa amat sangat beruntung telah didaftarkan oleh orang tuanya di sekolah miskin Muhammadiyah tersebut. Dan tak ada yang pernah tahu apa yang akan terjadi pada mereka semua setelah hari pertama masuk sekolah di bawah filicium tua itu, tetapi apapun itu pendidikan dan pengalaman yang mereka semua terima di sana adalah berharga.

Tiba-tiba aku merasa sangat beruntung didaftarkan orang tuaku di sekolah miskin Muhammadiyah. Aku merasa telah terselamatkan karena orang tuaku memilih sebuah sekolah Islam sebagai pendidikan paling dasar bagiku. Aku merasa amat beruntung berada di sini, di tengah orang-orang luar biasa ini. Ada keindahan di sekolah Islam melarat ini. Keindahan yang tak 'kan kutukar dengan seribu kemewahan sekolah yang lain. (Hirata, 2006:25)

\title{
Sumber Ekstrinsik: Sebuah Arus Surut
}

Laskar Pelangi mengambil latar di Belitong (Belitung), kampung halaman penulisnya, Andrea Hirata sendiri, di mana ia mengalami berbagai pengalaman dan kejadian yang kemudian ia tuliskan sebagai sumber inspirasi novel tersebut. Belitung, yang dulunya dikenal dengan Billitong, adalah sebuah pulau di lepas pantai timur Sumatra, Indonesia di Laut Jawa. Pulau ini terkenal dengan mericanya dan timah. Kota ini adalah sebuah kota yang kaya dengan limpahan hasil alam, tetapi masih mengalami keterbelakangan akibat kemiskinan.

Tak disangsikan, jika di-zoom out, kampung kami adalah kampung terkaya di Indonesia. Inilah kampung tambang yang menghasilkan timah dengan harga segenggam lebih mahal puluhan kali lipat dibanding segantang padi. Triliunan rupiah aset tertanam di sana, miliaran rupiah uang berputar sangat cepat seperti putaran mesin parut, dan miliaran dolar devisa mengalir deras seperti kawanan tikus terpanggil pemain seruling ajaib Der Rattenfanger von Hameln. Namun jika di-zoom in, kekayaan itu terperangkap di satu tempat, ia tertimbun di dalam batas tembok-tembok tinggi Gedong.

Hanya beberapa jengkal di luar lingkaran tembok tersaji pemandangan kontras seperti langit dan bumi. Berlebihan jika disebut daerah kumuh tapi tak keliru jika diumpamakan kota yang dilanda gerhana berkepanjangan sejak era pencerahan revolusi industri. Di sana, di 
luar lingkar tembok Gedong hidup komunitas Melayu Belitong yang jika belum punya enam anak belum berhenti beranak pinak. (Hirata, 2006:49-50)

Tak hanya mengalami fenomena kemiskinan yang parah akibat adanya monopoli PN (Perusahaan Negara) Timah yang menguasai perdagangan timah di sana tanpa memperhatikan kesejahteraan penduduk asli, Belitong juga mengalami ketertinggalan dalam bidang pendidikan seperti hampir sekian banyak daerah lain di Indonesia. Di Belitung, pendidikan masih dianggap sebagai "barang mewah" yang mahal dan tak terjangkau. Sementara dari kemiskinan mereka belum juga pulih, pendidikan pun menjadi sesuatu yang tak primer. Kesadaran demikianlah yang kemudian menggerakkan Andrea Hirata memutuskan untuk menuliskan tetralogi Laskar Pelangi, untuk menunjukkan kembali arti penting pendidikan dan geliat dari semacam refleksi potret pendidikan di negeri sendiri. Namun sesungguhnya, ada apa dengan realita pendidikan Indonesia, sehingga ia menjadi demikian semarak digugat dan "genting" untuk diangkat dalam sebuah novel seperti karya Andrea?!

Secara definitif, menurut Wikipedia Indonesia, pendidikan adalah: serangkaian usaha sadar dan terencana untuk mewujudkan suasana belajar dan proses pembelajaran agar peserta didik secara aktif mengembangkan potensi dirinya untuk memiliki kekuatan spiritual keagamaan, pengendalian diri, kepribadian, kecerdasan, akhlak mulia, serta keterampilan yang diperlukan dirinya dan masyarakat. Pendidikan meliputi pengajaran keahlian khusus dan juga sesuatu yang tidak dapat dilihat tetapi lebih mendalam, yaitu pemberian pengetahuan, pertimbangan dan kebijaksanaan. Salah satu dasar utama pendidikan adalah untuk mengajarkan kebudayaan lintas generasi.

Hampir tidak ada yang membantah bahwa pendidikan adalah pionir dalam pembangunan masa depan suatu bangsa. Adapun pertanyaan apakah pendidikan di Indonesia telah memenuhi kaidah atau kriteria dan mampu mencapai tujuan tersebut, merupakan perkara lain yang masih terus mengundang perdebatan dan pertanyaan demi pertanyaan lain yang tak akan habis-habis dibahas. Sebagai sebuah negara yang notabene kaya-raya dengan sumber daya alam yang melimpah, Indonesia masih mengalami ketertinggalan dalam hal pendidikan dan pengembangan sumber daya manusia.

Dilansir dari Sinar Indonesia Baru 08 November 2006, besarnya angka kemiskinan di Indonesia saat itu setara dengan kondisi 15 tahun sebelumnya. Berdasarkan data Biro Pusat Statistik (BPS), penduduk miskin pada tahun 2004 berjumlah 36,1 juta orang atau 16,6 persen dari seluruh penduduk Indonesia. Tingkat kemiskinan dan pengangguran di Indonesia masih paling tinggi di antara negara-negara ASEAN. Demikian pula dalam indeks pembangunan manusia HDI (Human Development Index), Indonesia masih menempati peringkat 111 dari 175 negara di dunia. Posisi ini jauh di bawah negara tetangga Malaysia (76) dan Filipina (98).

Dr. Francis Wahono, aktivis organisasi non-pemerintah yang bergerak dalam bidang pendidikan di masyarakat bawah mengemukakan apabila proses involusi yang tengah terjadi dalam pendidikan di Indonesia dibiarkan terus berlangsung, dalam kurun waktu tujuh sampai sepuluh tahun mendatang Indonesia akan menjadi bangsa paria di kawasan Asia Tenggara. "Kinerja sektor pendidikan kita sungguh mengenaskan. Indeks pembangunan manusia (HDI), yang menempatkan Indonesia di peringkat ke-111, mencerminkan betapa miskinnya pemikiran dan kacaunya penyelenggaraan pendidikan di Tanah Air," kata Wahono. (Kompas, Sabtu, 04 September 2004)

Potret pendidikan saat proses kreatif novel ini, masih diragukan kemampuannya untuk mencerdaskan dan dengan demikian mampu melepaskan belenggu masyarakat dari kemiskinan. Di sisi lain, kaum miskin menjadi kaum terlarang untuk memasuki kawasannya. "Orang miskin dilarang sekolah!" demikian dikutip dari www.wikimu.com, menyangkut mahalnya biaya pendidikan di negeri ini. Lalu pendidikan itu diperuntukkan siapa? Hanya segelintir kaum kelas atas sajakah? Sementara mengenai jumlah, mereka tidaklah begitu besar 
jika dibandingkan dengan kaum kelas bawah. Tampak terang, kebijakan-kebijakan pendidikan yang dibuat pemerintah menjadi cermin betapa buruknya negara ini mengelola pendidikan.

Pendidikan Indonesia tengah mengalami proses involusi dan bergerak tanpa arah yang jelas. Dari hari ke hari manusia yang terlibat dalam pendidikan bukannya tumbuh kian cerdas, tetapi mutunya semakin menurun meski input fasilitas fisiknya terus bertambah. Ketidakjelasan arah pendidikan itu menyebabkan pendidikan di Indonesia tidak kompetitif lagi dibandingkan dengan pencapaian negara-negara lain, bahkan di wilayah Asia Tenggara sekalipun. (Kompas, Sabtu, 04 September 2004).

Padahal dalam anggaran yang disusun oleh pemerintah setiap tahun, pendidikan pun telah mendapatkan porsi perhatian, tetapi tentu ada semacam sistem yang berlangsung secara tak benar sehingga pendidikan tak juga maju-maju di negeri ini. Dalam APBN 2007, anggaran untuk sektor pendidikan adalah sebesar Rp90,10 triliun atau 11,8 persen dari total nilai anggaran Rp763,6 triliun. (www.tempointeraktif.com, 8 Januari 2007). Angka Rp90,10 triliun itu belum termasuk pengeluaran untuk gaji guru yang menjadi bagian dari Dana Alokasi Umum (DAU) dan Dana Alokasi Khusus (DAK) untuk bidang pendidikan, serta anggaran kedinasan.

Namun, mewujudkan pendidikan yang berkualitas di Indonesia sebenarnya bukanlah hal yang tidak mungkin. Yang menjadi masalah sebenarnya bukan tidak adanya potensi pembiayaan, melainkan ketidakbecusan dalam mengelolanya. Pendidikan mahal bukan disebabkan tidak adanya sumber pembiayaan, melainkan disebabkan kenyataan pemerintahan yang bobrok dan korup. Jadi seperti SD Muhammadiyah Belitong, hanyalah salah satu dari sekian "korban" tersebut. Maka tidak mengherankan jika tetap saja akan ada sekolah-sekolah miskin yang kurang mendapat perhatian dari pemerintah, kekurangan fasilitas dan tenaga pengajar dan guru-guru bergaji kecil atau pula kenyataan bahwa para siswa kini lebih suka tawuran daripada belajar. Pendidikan telah menjadi barang yang begitu mewah, yang hanya sanggup "dibeli" oleh mereka yang bermodal tebal. Dan di negeri Indonesia ini, akan tetap bermunculanlah anak-anak semacam anggota Laskar Pelangi yang lain, mereka berusaha untuk mengambil dan menikmati apa yang terbaik dari keadaan terburuk yang negeri ini miliki: pendidikan itu sendiri.

"Mahalnya biaya pendidikan itu buah dari kebijakan pemerintah yang mengadopsi
ideologi penjajah kafir khususnya AS, yakni neoliberalisme. Sebagai salah satu
varian kapitalisme--seperti Keynesian yang mengutamakan intervensi pemerintah-
-neoliberalisme justru sebaliknya. Neoliberalisme merupakan bentuk baru
liberalisme klasik dengan tema-tema pasar bebas, peran negara yang terbatas, dan
individualisme. (Adams, 2004)"

Sayang sekali, Pemerintah yang semestinya bertindak bagaikan penggembala, telah berubah fungsi menjadi serigala buas yang tega menghisap darah rakyatnya sendiri. Di tengah kesulitan hidup yang berat karena kemiskinan, pendidikan mahal akibat tunduk pada agenda neoliberalisme global, semakin melengkapi kegagalan pemerintah sekuler saat ini. (Al-Jawi: Blog Pendidikan Indonesia, 20 Mei 2007)

Bicara pendidikan Indonesia adalah menguak semacam luka kronis yang dari sistem yang tak habis-habis harus dikritisi dan dikoreksi. Padahal jika pemerintah hendak bersungguhsungguh, impian untuk dapat memberikan pelayanan pendidikan secara total dan gratis, pun dapat diwujudkan. Seperti kenyataan para pelajar di SDN Cakung Permata Nusa di kawasan perkebunan sawit PT. Astra Agro Lestari di Kabupaten Tabalong, Kalimantan Selatan, yang telah menikmati pendidikan gratis. Hal ini merupakan semacam kelegaan di antara serangkaian "berita buruk" percakapan tentang pendidikan.

Bupati Musi Banyuasin, Alex Noerdin, ketika berbicara dalam Nation Stakeholder Meeting Education for All in an Inclusive Setting di Yogyakarta, Senin (14/5/2007), dengan 
bangga menuturkan bahwa sejak 2002, 119 ribu siswa mulai dari TK hingga SMA di kabupaten yang dipimpinnya telah menikmati pendidikan gratis.

Total anggaran pendidikan di kabupaten tersebut, paparnya, sebesar Rp345,6 miliar atau 21,74 persen dari total APBD, sehingga sudah melebihi batas minimal yang ditentukan UUD 1945. (Suara Pembaruan, 16 Mei 2007)

Jadi, untuk mewujudkan kualitas pendidikan terbaik tanpa biaya bukan hanya semacam idealisme tak kesampaian yang harus diterapkan oleh pemerintah Indonesia. Apa yang paling perlu untuk dilakukan adalah mengurai kembali benang kusut sistem pendidikan negeri untuk meluruskannya dan mengarahkannya ke arah yang lebih baik, seperti pada Visi Indonesia 2030.

Menurut Parera, Philip Kotler (Prasetya, Kompas 30 Mei 2007) dalam penelitiannya menyatakan "Pendidikan formal berperan strategis dalam pembangunan ekonomi". Tanpa pendidikan, berdiri kokoh penghalang upaya pembangunan ekonomi. Melalui manusia terdidik akan diseminasikan nilai-nilai yang relevan dengan pembangunan ekonomi.

Di bidang pendidikan, pada 2015 semua anak, baik laki-laki maupun perempuan harus dapat menyelesaikan pendidikan dasar. Sepanjang waktu, kebijakan dan praksis pendidikan seluruhnya tidak bisa dibebaskan dari politik kekuasaan. Dalam kondisi seperti itu, komitmen untuk mengutamakan kepentingan bersama guna memajukan pendidikan adalah mutlak. Apalagi jika pendidikan diharapkan berkontribusi bagi kemajuan ekonomi. (Prasetya, Kompas 07 Mei 2007)

Barangkali sebagai semacam ilustrasi, negara kita perlu meneladani Finlandia yang diakui sebagai negara dengan kualitas pendidikan terbaik di dunia. Finlandia mengalahkan 40 negara lain di dunia berdasar survei PISA yang dilakukan oleh OECD (Organization for Economic Cooperation and Development) tahun 2003. Tes komprehensif dilakukan melalui pengukuran kemampuan mathematics, reading, science, dan problem solving yang ditujukan untuk peningkatan kualitas sistem pendidikan. Tes ini dilakukan per tiga tahun--tes terakhir dilakukan pada tahun 2006 dan hasilnya keluar akhir 2007. Finlandia bukan hanya unggul secara akademis tapi juga menunjukkan unggul dalam pendidikan anak-anak lemah mental. Ringkasnya, Finlandia berhasil membuat semua siswanya cerdas.

Sementara, nilai Indonesia sendiri untuk tes yang sama, masih begitu jauh di bawah rata-rata. Seperti dilansir dari www.nofieiman.com, pada matematika dengan nilai rata-rata 484.84 poin, Finlandia menerima 544.29 dan Indonesia hanya 360.16. Untuk membaca, dengan nilai rata-rata 480.22, Finlandia menerima 543.46 dan Indonesia hanya 381.59. Untuk sains dengan nilai rata-rata 487.77, Finlandia menerima 548.23 dan Indonesia hanya 395.04. Untuk kategori pemecahan masalah dengan nilai rata-rata 485.20, Finlandia menerima 547.61 dan Indonedia hanya 361.42. Sementara untuk total skor keseluruhan dengan nilai rata-rata 484.51, Finlandia menerima 545.90 dan Indonesia hanya 374.55. Sungguh merupakan sebuah kenyataan yang memilukan dan memalukan!

Rahasia sukses Finlandia menjadi sedemikian maju dalam bidang pendidikan adalah serangkaian formula yang layaknya juga perlu dan harus turut diterapkan di Indonesia. Dari segi anggaran, Finlandia agak sedikit lebih tinggi dari negara lain--walau bukan yang tertinggi. Kegiatan sekolah juga hanya 30 jam per minggu. Namun, guru-guru di Finlandia adalah pilihan dengan kualitas terbaik. Untuk menjadi guru jauh lebih ketat persaingannya ketimbang melamar Fakultas Hukum atau Kedokteran. Guru juga diberi kebebasan dalam menyusun kurikulum, memilih text-book, hingga metode pengajaran dan evaluasi.

Sistem pendidikan Finlandia memang unik. Orientasi dibuat untuk tujuan-tujuan yang harus dicapai. Penekanan ada di proses, bukan hasil. PR dan ujian tidak mesti dikerjakan dengan sempurna--yang penting murid menunjukkan adanya usaha. Ujian justru dipandang sebagai penghancur mental siswa. Sejak awal, murid diajari bertanggung jawab mengevaluasi dirinya sendiri. Mereka didorong untuk bekerja secara independen. Guru tidak mesti selalu mengontrol 
mereka. Proses pembelajaran berjalan dua arah. Suasana sekolah boleh dikatakan jadi lebih cair, fleksibel, dan menyenangkan tetapi efektif. Guru juga tak pernah mengkritik murid yang justru dinilai membuat murid malu dan menghambat proses pembelajaran itu sendiri. Murid "boleh" berbuat kesalahan, tetapi guru akan memintanya untuk membandingkan dengan hasil capaiannya sendiri sebelumnya. Memang tak ada sistem ranking di sini sehingga siswa merasa confident dan nyaman terhadap dirinya. Ranking dipandang hanya membuat guru berfokus pada murid-murid terbaik saja, bukan ke seluruh murid. Secara garis besar: Finlandia sukses menggabungkan kompetensi guru yang tinggi, kesabaran, toleransi dan komitmen pada keberhasilan melalui tanggung jawab pribadi. Kemudian membayangkan sebuah keadaan di masa depan: masa ketika pendidikan Indonesia dapat berkembang sedemikian maju dengan begitu membanggakan. Masa ketika pendidikan Indonesia telah mampu tumbuh subur, kokoh dan rindang. Masa ketika pendidikan Indonesia mewujud sebatang pohon: filicium, yang akan selalu memasok keberlangsungan hidup bagi ekosistem di sekitarnya.

\section{SIMPULAN}

Pendidikan Indonesia sedang berada pada ketidakjelasan involusi: sebuah potret pasang-surut yang memerlukan penanganan segera, dan menarik perhatian serta menuntut kesadaran dari segenap pihak yang peduli atas nasib masa depan negeri ini. Kenyataan tersebut pun turut menimbulkan perhatian di bidang sastra yang mulai tergerak untuk menggarap karya dengan tema-tema pendidikan--yang agak jarang terjamah oleh para penulis sebelumnya. Salah satunya adalah Andrea Hirata, yang berani menjawab tantangan tersebut dan menerbitkan tetralogi Laskar Pelangi sebagai kontribusi kepedulian dan perhatiannya pada pendidikan.

Laskar Pelangi merupakan bagian pertama dari rangkaian novel tetralogi karya Andrea Hirata, sebuah novel semi-autobiografi yang berangkat dari keterlibatan Andrea sendiri atas pengalamannya bersama anggota Laskar Pelangi yang lain dalam buruknya kualitas dunia pendidikan di Indonesia, dan berhasil merefleksikan realitas tersebut dengan lugas dan tepat. Laskar Pelangi juga turut mewakili kecemasan masyarakat Melayu Belitong (Belitung) yang kian dirundung kemiskinan, meskipun pada kenyataannya mereka hidup di tanah yang melimpah dengan segala hasil sumber daya alam. Novel tersebut mampu menghadirkan semacam kritik dan kesadaran untuk memperbaiki keadaan tersebut.

\section{DAFTAR PUSTAKA}

Adams, Ian. 2004. Ideologi Politik Mutakhir (Political Ideology Today). Yogyakarta: Penerbit Qalam. Ahmad, Djauzak. 2004. Kemiskinan dan Kesempatan Memperoleh Pendidikan. Kompas (05 Agustus 2004).

Al-Jawi, KH. M. Shiddiq. "Pembiayaan Pendidikan dalam Islam". Blog Pendidikan Indonesia. (http://education-indonesia.blogspot.com/2007/05/pembiayaan-pendidikan-dalam-islam.html)

Anggraini, Nani. 2019. Analisis Strukturalisme Genetik dalam Novel Midah Simanis Bergigi Emas Karya Pramoedya Ananta Toer. https://core.ac.uk/download/pdf/270282565.pdf

Fitria. 2017. Strukturalisme Genetik dalam Novel Fadaituki Ya Laila Karya Yusuf Siba'i. https://repository.ar-raniry.ac.id/

Goldmann, Lucien. 1977. The Hidden God. London: Routledge and Kegan Paul.

Hirata, Andrea. 2006. Laskar Pelangi. Yogyakarta: Bentang.

Iman, Nofie. 2007. "Pendidikan Indonesia Terbaik di Dunia?" (http://nofieiman.com/2007/05/pendidikan-indonesia-terbaik-di-dunia/).

Iswanto. 1994. Teori Penelitian dalam Perspektif Strukturalisme Genetik Masyarakat Poetika Indonesia. Jogjakarta: IKIP Muhammadiyah.

Jabrohim (ed). 1994. Pengajaran Sastra. Yogyakarta: Pustaka Pelajar Bekerjasama dengan FPBS IKIP Muhammadiyah.

Jabrohim (ed). 2002. Metodologi Penelitian Sastra. Jogyakarta: Hanindita Graha Widya. 
Mustomi, T., \& Munir, S. 2018. Kajian Strukturalisme Genetik dalam NovelEliana Karya Tere Liye. https://jurnal.unigal.ac.id/index.php/literasi/article/view/1227/1104

Prasetya, Erwin Edhi. 2007. "Visi Indonesia 2030 dan Pendidikan: Kontribusi untuk Masa Depan Ekonomi". Kompas: Humaniora (07 Mei 2007).

Prasetya. Erwin Edhi. 2007. Visi 2030 dan Pendidikan (2); Kontribusi Untuk Masa Depan Ekonomi. Kompas Humaniora (30 Mei 2007)

Ryan, Michel. 1999. Literary Theory: A Practical Introduction. Massachusets: Blackwell Publishers Inc.

Saputro, Andri Aji. "Kualitas Pendidikan Terbaik di Dunia". Blog Pendidikan Indonesia. (http://education-indonesia.blogspot.com/2007/05/pembiayaan-pendidikan-dalam-islam.html)

Wikipedia. 2007. Education. Wikipedia, the free encyclopedia. (http://en.wikipedia.org/wiki/Education).

Wikipedia. 2007. Andrea Hirata. Wikipedia Indonesia, ensiklopedia bebas berbahasa Indonesia. (http://id.wikipedia.org/wiki/Andrea_Hirata).

Wikipedia. 2007. Laskar Pelangi. Wikipedia Indonesia, ensiklopedia bebas berbahasa Indonesia. (http://id.wikipedia.org/wiki/Laskar_Pelangi).

Wikipedia. 2007. Kepulauan Bangka Belitung. Wikipedia. Indonesia,ensiklopedia.bebas berbahasa Indonesia (http://id.wikipedia.org/wiki/ Kepulauan_Bangka_Belitung).

Wikipedia. 2007. Pendidikan. Wikipedia Indonesia, ensiklopedia bebas berbahasa Indonesia. (http://id.wikipedia.org/wiki/Pendidikan).

Wikipedia. 2007. Pulau Belitung. Wikipedia Indonesia, ensiklopedia bebas berbahasa Indonesia. (http://id.wikipedia.org/wiki/Pulau_Belitung). 2004. Pendidikan Indonesia Alami Proses Involusi. Kompas. (04 September 2004).

2004. Permasalahan Pendidikan Indonesia Perlu Dipetakan Kembali. Kompas: Humaniora (14 Oktober 2004).

. 2005. Pendidikan, Kemiskinan dan Keadilan. Mirifica: E-News. (http://mirifica.net/wmview.php?ArtID=1741). . 2006. Membangun Pendidikan, Mengatasi Kemiskinan. Sinar Indonesia Baru (08 November 2006). . 2007. Pendidikan Gratis Bukan Hal Mustahil. Suara Pembaruan (16 Mei 2007). 